its abilities. (This article has appeared in Change and is reprinted here with permission).

\section{Affirmative Action Initiatives Around the World}

\section{Laura Dudley Jenkins and Michele S. Moses}

Laura Dudley Jenkins is associate professor of political science at the University of Cincinnati. E-mail: Laura.Jenkins@uc.edu. Michele S. Moses is professor of educational foundations, policy, and practice, at the University of Colorado Boulder.E-mail: michele.moses@colorado. edu. Additional discussion can be found in L. D. Jenkins and M. S. Moses, eds. Affirmative Action Matters: Creating Opportunities for Students Around the World (New York: Routledge, 2014).

T s affirmative action in higher education on its way out? If you take a global perspective, the answer is "no." In April 20I4, the US Supreme Court's decision in Schuette v. Coalition to Defend Affirmative Action reinforced a common perception that affirmative action will not be around for much longer. Schuette makes it even more difficult for some American colleges and universities to engage in affirmative action by affirming the constitutionality of state ballot initiatives that ban affirmative action programs. Yet about one quarter of the countries of the world have some form of affirmative action in student admissions into higher education, and many of these programs have emerged over the last 25 years.

This is just one of the findings drawn from a new country-by-country database on affirmative action for students in higher education worldwide. Three significant patterns emerge from these data. First, as noted above, affirmative action policies have expanded globally in the last quarter century. A second finding is the salience of gender. Gender is the most prominent demographic category used for eligibility for affirmative action, rivaling race, ethnicity, and class/income. A third trend is that institutions of higher education and governments have been experimenting with race-neutral affirmative action policies or multifaceted notions of disadvantage, in response to legislative threats, legal challenges, or social criticism.

\section{Countries That Have Affirmative Action}

About one quarter of nations across the world use some form of affirmative action for student admissions into higher education. Although these policies go by many names-affirmative action, reservations, alternative ac- cess, positive discrimination-all are efforts to increase the numbers of underrepresented students in higher education. Various institutions or governments on six continents (Africa, Asia, Australia/Oceania, Europe, North America, and South America) have programs to expand admissions of nondominant groups on the basis of race, gender, ethnicity, class, geography, or type of high school.

Several combine these categories. These combinations show that policies to offset racism or other forms of xenophobia can complement policies to fight economic disadvantages. Although some nations-such as India, Tanzania, and the United States-have had affirmative action policies and programs for a longer time period, most programs for students in higher education started in the I990s or 2000 s.

\section{Gender a Popular Policy Target}

Another finding is the popularity of policies targeting women. These policies may get less attention in some cases than those targeting underrepresented racial or ethnic groups, but they increasingly dominate the affirmative action landscape. Programs that started more recently are more likely to include women. Even more countries have programs to advance schooling for girls. More countries have genderconscious affirmative action than any other type of policy target. When women are overrepresented in colleges and universities, some of these affirmative action policies are specific to certain fields in which women remain underrepresented.

\section{About one quarter of the countries of the world have some form of affirmative ac- tion in student admissions into higher education, and many of these programs have emerged over the last 25 years.}

The next most popular foci for affirmative action efforts are ethnicity (including policies organized by ethno-regions) and class (which is also sometimes conceptualized by residence, namely areas determined to be underprivileged). Less prevalent are policies based on race or disability, and rarest of all are caste-based policies, although their implementation in India means that the population of students eligible for caste-based affirmative action is substantial. 


\section{BEYOND RACE}

Programs in several countries target multiple forms of social inequality and avoid solely race-conscious policies. Brazilian affirmative action is race-conscious but also includes other students considered to be disadvantaged, such as graduates of government secondary schools or students with low-family income. Even South Africa, only free from apartheid for two decades, has some alternate access programs that have begun admitting disadvantaged white students, and other admissions programs consider a range of socioeconomic indicators related to housing, schooling, and family circumstances.

Some policies attempt to combine poverty with other indicators of disadvantage to select students, such as French policies prioritizing and recruiting from low-income neighborhoods or schools, based in ZEPs (Zones d'Education Prioritaire, or priority education areas). An inverse strategy to achieve similar ends excludes the wealthy, as in India's policy of skimming the economic "creamy layer" of more prosperous individuals from eligibility for reserved seats for the groups officially designated as "Other Backward Classes" - a category that already combines both caste- and class-conscious criteria. Israel has successfully integrated ethnicity/nationality and socioeconomic status as targets of affirmative action programs aimed at diversifying selective higher education institutions. Admissions categories focus on the structural challenges students face based on living in disadvantaged neighborhoods and attending low-quality secondary schools.

\section{IMPLICATIONS}

What are the implications of these international policy examples for countering social inequality in higher education? Affirmative action is not a comprehensive solution for poverty or discrimination, but systems of higher education can provide more equitable chances for impoverished or underrepresented students to attend selective colleges and universities. Indices, zones, and other measures are not replacing the role of race, ethnicity, or gender in welldesigned affirmative action programs but are increasingly combined with these categories.

So long as past or present racism, casteism, sexism, or other barriers shape opportunities in a particular society, equity policies can be better designed to reflect and counteract the way multiple forms of disadvantage intersect in the lives of students. Whether motivated by a desire to increase access, expand diversity, or simply recalibrate existing policies in response to court rulings or state referenda, administrators and policymakers should look abroad for ideas. Affirmative action is alive and well-and indeed increasing-around the world.

\section{The Economic and Non-} economic Benefits of Tertiary Education in Low-income Contexts

\author{
Rebecca Schendel, Tristan McCowan, and Moses \\ OKETCH
}

Rebecca Schendel is lecturer in Education a International Development, Tristan McCowan is senior lecturer in Education Q International Development, and Moses Oketch is reader in Education Q International Development at the Institute of Education, University of London. E-mails:r.schendel@ioe.ac.uk; t.mccowan@ioe.ac.uk; m.oketch@ioe. ac.uk. Material for this article comes from: Oketch, McCowan, and Schendel, The Impact of Tertiary Education on Development: A Rigorous Literature Review. Download the full review at: http://r4d.dfid.gov. uk/Output/195887/.

$\mathrm{T}$ There have been debates around the social impact of tertiary education in developing countries for decades. In the late I980s, a series of studies commissioned by the World Bank seemed to indicate that, in developing contexts, investment in tertiary education would yield a much lower social return than that in lower levels of education. In contexts where primary education was scarce and illiteracy was rampant, there was a clear economic argument for prioritizing basic education to fuel economic growth. These economic arguments were also supported by social justice concerns that emphasized the ways in which university admissions processes disadvantaged marginalized groups. In contexts where only a small proportion of the population reaches university, advocates for prioritizing funding for primary education have long argued that public support for higher education is likely to perpetuate socioeconomic divisions within society. Although these concerns were valid in many contexts, the unfortunate result was a reduction in both international aid and domestic funding for tertiary education in many low-income contexts, a decision that triggered a "crisis of quality" across the sector.

However, shifts in the nature of production associated with globalization and the rise of the "knowledge economy," as well as increasing demand as a result of expanding primary and secondary enrollment, have redirected international attention to the importance of tertiary education in development. Development agencies and national governments are now considering renewing their financial commitment to tertiary education; and, as a result, the question of impact has returned to the discourse. In line with these developments, the Institute of Education, University 